\title{
HEALTH SHOCKS, INSURANCE STATUS AND NET WORTH: INTRA- AND INTER-GENERATIONAL EFFECTS
}

\author{
Dalton Conley \\ Jason Alan Thompson \\ Working Paper 16857 \\ http://www.nber.org/papers/w16857
NATIONAL BUREAU OF ECONOMIC RESEARCH
1050 Massachusetts Avenue
Cambridge, MA 02138
March 2011

This research was funded by the National Science Foundation's Alan T. Waterman Award, SES-0540543. This work was also supported by a grant from the University of Michigan's Panel Study of Income Dynamics small grants program. The views expressed herein are those of the authors and do not necessarily reflect the views of the National Bureau of Economic Research.

NBER working papers are circulated for discussion and comment purposes. They have not been peerreviewed or been subject to the review by the NBER Board of Directors that accompanies official NBER publications.

(C) 2011 by Dalton Conley and Jason Alan Thompson. All rights reserved. Short sections of text, not to exceed two paragraphs, may be quoted without explicit permission provided that full credit, including (C) notice, is given to the source. 
Health Shocks, Insurance Status and Net Worth: Intra- and Inter-Generational Effects

Dalton Conley and Jason Alan Thompson

NBER Working Paper No. 16857

March 2011

JEL No. I1,J14

\begin{abstract}
$\underline{\text { ABSTRACT }}$
An extensive literature has documented a robust correlation between socioeconomic status-measured in a variety of ways - and health outcomes; however, much uncertainty remains regarding what causal processes underlie this association. The present paper builds on a growing literature that seeks to better document how and why wealth and SES are related. Specifically, we ask the extent to which health shocks affect net worth - a less-studied dimension of socioeconomic status. Given a lack of instruments that meet the exclusion restriction, we use data from the Panel Study of Income Dynamics to pursue a first-differences identification strategy. We estimate a parameter for acute illnesses (which should have a causal effect on wave-to-wave wealth changes) and compare this coefficient to a counterfactual parameter for the presence of chronic illnesses (which we argue should be less causally related to wealth differences year-to-year). Additionally, we interact these health indicators with insurance status as a further test that the health-wealth relationship is likely causal net of covariates. Results show that the onset of an acute illness has a negative effect on family wealth levels and that the onset of chronic illnesses only makes an impact when it occurs for those uninsured. In intergenerational models, parental health insurance status also seems to matter. When parents suffer from chronic illness and have no health insurance, adult children's net worth declines. Adult children in white families also face a greater likelihood of falling into debt (excluding wealth from home equity) when parental medical expenses increase. Together, these findings suggest that health dynamics play an important role in intergenerational stratification processes - at least under the current health regime of the United States.
\end{abstract}

\author{
Dalton Conley \\ New York University \\ 6 Washington Square North \#20 \\ New York, NY 10003 \\ and NBER \\ conley@nyu.edu \\ Jason Alan Thompson \\ New York University \\ 295 Lafayette Street 4th Floor \\ New York, NY 10003 \\ jason.thompson@nyu.edu
}




\begin{abstract}
An extensive literature has documented a robust correlation between socioeconomic status - measured in a variety of ways - and health outcomes; however, much uncertainty remains regarding what causal processes underlie this association. The present paper builds on a growing literature that seeks to better document how and why wealth and SES are related. Specifically, we ask the extent to which health shocks affect net worth-a less-studied dimension of socioeconomic status. Given a lack of instruments that meet the exclusion restriction, we use data from the Panel Study of Income Dynamics to pursue a first-differences identification strategy. We estimate a parameter for acute illnesses (which should have a causal effect on wave-to-wave wealth changes) and compare this coefficient to a counterfactual parameter for the presence of chronic illnesses (which we argue should be less causally related to wealth differences year-toyear). Additionally, we interact these health indicators with insurance status as a further test that the health-wealth relationship is likely causal net of covariates. Results show that the onset of an acute illness has a negative effect on family wealth levels and that the onset of chronic illnesses only makes an impact when it occurs for those uninsured. In intergenerational models, parental health insurance status also seems to matter. When parents suffer from chronic illness and have no health insurance, adult children's net worth declines. Adult children in white families also face a greater likelihood of falling into debt (excluding wealth from home equity) when parental medical expenses increase. Together, these findings suggest that health dynamics play an important role in intergenerational stratification processes — at least under the current health regime of the United States.
\end{abstract}




\section{Introduction}

While health-SES gradients have been established across time and place, a robust debate continues as to the causal directionality (and mechanisms) that generate these observed associations. Many researchers have shown independent effects of socioeconomic variables on health status - measured in a variety of ways. For example, Strully (2008) shows that "exogenous" (i.e. no-fault) job loss increases likelihood of acute illness (while not affecting incidence of chronic conditions). Lleras-Muney (2005), meanwhile, deployed changes in state compulsory schooling laws during the early $20^{\text {th }}$ Century to estimate the impact of additional (high school) years of schooling on mortality. She finds that each additional year of formal education extends life expectancy by 10 percent (a figure that is actually higher than most OLS estimates, a fact attributed to the fact that she was estimating a LATE for secondary schooling, where effects may be strongest). However, other researchers have found evidence for a more complicated relationship between SES and health. For example, Ruhm et al. (2005) find that for males ages 18 to 35, mortality is countercyclical; likewise, Evans and Snyder (2006) use the discontinuity of the social security "notch" to show that additional income reduces the life expectancy of those aged 65 and above. The mechanism appears to be that higher pension income leads to greater withdrawal from the labor market — which itself is detrimental to health and longevity.

Meanwhile, some researchers have established that health status can affect SES. For example, Conley and Bennett (2000; also see Conley, Strully and Bennett 2003; Conley, Pfeiffer and Velez 2006) show that while maternal income does not significantly impact a child's birth weight, the birth weight of the child does indeed predict test scores and educational attainment. Further analyses posit connections between general childhood health and childhood obesity with 
diminished educational attainment (Rappaport and Robbins 2005; Jackson 2009). Additionally, Averett and Korenman (1996) and Conley and Glauber (2006) argue that—for white women, at least—overweight or obese status depresses income (largely through its effects in the marriage market).

The above mentioned examples deal with education, employment and income. However, net worth has also been shown to be an important component of socioeconomic statusparticularly with respect to race differences (Oliver and Shapiro 1995; Conley 1999) and in regards to the transmission of educational advantage to offspring (Conley 2001). Yet, net worth has been understudied in the health-SES literature. Meer, Miller and Rosen (2003) instrument wealth using inheritance (under the assumption that its timing is fairly random and therefore families do not smooth consumption in anticipation of receiving it) and find no relationship between wealth and subjective health. Yeung and Conley (2008) show an association between family wealth and children's math test scores net of a host of covariates, but this, too, fails to survive instrumentation using the same inheritance strategy. However, to the extent that receiving inheritance implies the recent death of a beloved kin or friend, it is a less than ideal instrument. Namely, bereavement has been shown to be just the kind of stress that negatively affects health. That is, by depressing health status directly, death-associated inheritance violates the exclusion restriction and leads to attenuation bias. So it is not surprising that Meer, Miller and Rosen as well as Yeung and Conley, respectively, cannot find significant effects using such a strategy.

Utilizing the Health and Retirement Survey (HRS), other researchers note the healthwealth correlations for individuals who are retired or nearing retirement. In these studies, the goal is to examine how health factors in to income and wealth in the later stages of life. Smith 
(2004) highlights the impact of major and minor health shocks on out-of-pocket medical expenses, participation in the labor force, household income and household wealth. Additionally, Coile and Milligan (2009) and Poterba et al. (2010) analyze the effect of health shocks on wealth accumulation. Each analysis offers support to the hypothesis that health plays a significant role for the accumulation of assets over the life course. While these studies offer insight into the design of our analyses, they unfortunately limit their scope to the aging populations in the HRS.

Likewise, a recent paper by Monahan (2008) treats bus accidents among regular Indian bus riders as random as compared to non-affected commuters who utilize the same companies. In this study, Monahan finds that those injured in such road accidents are about 30 percentage points more likely than their "control" group bus rider counterparts to have to borrow money in that given year and/or to be in net debt over that period. While this paper effectively demonstrates a causal link between accident and injury, on the one hand, and negative wealth shocks on the other, its external validity is perhaps limited to the developing world context (and also perhaps to the case of accidents).

By contrast, as outlined below, we present data for individuals and households largely still in the labor market and broaden our focus to include the health-wealth relationship across generations in the United States for a population that is more nationally representative with respect to age than the HRS sample. Given the paucity of wealth instruments that do not violate the exclusion restriction (and conversely, the lack of health instruments that do not have direct effects on wealth accumulation in the developed world context), in the present paper we pursue a different strategy to try to estimate the relationship between health and wealth. Namely, we look at wave-to-wave changes in net worth using a first-difference approach. In this framework we 
particularly focus on the estimated coefficients for "acute" and "chronic" illness. Since we use a first-difference model, these parameters are identified by years in which there was a change in health status from the previous wave. In other words, when an acute illness strikes, we expect that to negatively influence net worth during that same period particularly (conditional on insurance status); and conversely, when an acute condition ameliorates, we expect an increase in net worth for that given period. The persistence of (or coincidental sequential arrival of) an acute condition across two or more waves would only contribute to the estimated parameter for the waves in which it first appears and the wave in which it relents. Of course, we will be controlling for the presence or absence (i.e. the change from the previous wave) in chronic conditions as well. We expect that chronic conditions - even in a first difference model—are more likely to be endogenously associated with net worth given that such conditions tend to develop and present over a long period of time and thus provide a counterfactual. Likewise, for those with health insurance, we expect that the shock of acute illness should result in a negative effect on net worth that would be at least partially spurious since most major medical expenses would be covered — though, of course, a serious illness or injury may require payments over and above insurance coverage depending on the quality of the policy and the nature of the health shock and/or require families to draw down savings in the case of extended labor market absence.

\section{Data and Methods}

The Panel Study of Income Dynamics (PSID) originated in 1968 with a nationally representative sample of 5,000 American families. The survey follows each family every year to track economic (and health) data. As individuals move out of a family unit to start their own 
families, the PSID adds the newly-formed unit to the sample. The latest release of data collected in 2007 provides information on over 8,000 families in the United States. As the longest-running longitudinal study on family and individual dynamics, the study design is much too complex to detail in full here. (Please see Hill (1992) or Duncan and Hill (1989) for fuller descriptions.) Regardless, the study complexity provides us with the ability to follow the family economic and health histories of children born into sample families and the families formed as those children reach an age to form their own family units.

To examine the role of health in intra- and intergenerational wealth volatility we form two separate samples from the data provided in the PSID. First, due to the collection years for the data on family wealth, we truncate both of our samples to include all of the waves in the study which note wealth levels. This limits our analysis to the eight waves of data for which family wealth variables exist $-1984,1989,1994,1999,2001,2003,2005$ and 2007. For the intra-generational analysis, we select adult respondents ages 25 to 45 in 1984 who were head or wife of their household in any (or all) years between 1984 and 2007. We select one random adult person per household (either husband or wife) and follow them to 2007 when they are between the ages of 48 and $68 .^{1}$

For the intergenerational analysis, we select PSID individuals who were co-resident sons or daughters of the head or wife ${ }^{2}$ in the 1984 sample who were between the ages of 3 and 21 in that survey year. We follow these offspring over the next 23 years of the survey until the family members reach between the ages of 25 and 45 (this wider age band is a result of the timing of the survey with respect to selected respondents' birthdays). To study the impact of health on wealth

\footnotetext{
${ }^{1}$ Given that many variables are coded at the family level, we randomly select one adult per household, rather than examine all members, as to not double-count many of our measures, which may bias results.

${ }^{2}$ The PSID codes wives and cohabitating partners (“wives") separately. For our analysis we included both wives and cohabitating partners.
} 
volatility across generations, the intergenerational sample includes only individuals who moved out of their original family unit to start their own family (otherwise, the wealth measured would be the parents' and not that of the offspring). Therefore, the co-resident sons and daughters in 1984 must have spent at least one wave of the $1999-2007$ survey years ${ }^{3}$ in their own established family unit to be included in our intergenerational sample. This was to ensure that the children of sample families have completed formal education and had the opportunity to begin accruing their own assets.

The measures used to model intra- and inter-generational volatility in net worth are described below.

Household Wealth: This variable is taken from the 1984, 1999, 2001, 2003, 2005 and 2007 waves of the PSID. The PSID codes family wealth with and without the value of home equity. Wealth is calculated by adding the values of family business or farm, checking and savings, real estate other than main home, stocks and mutual funds, vehicles, bonds and life insurance policies, Individual Retirement Accounts and annuities, minus any debts. The PSID calculates wealth with home equity in nearly the same manner, merely adding the value of the main home - minus any outstanding mortgages associated with the property.

Our main outcome variables include wealth and wealth with home equity in 2009 dollars. We present estimates of the natural logarithm of these measures of wealth—with individuals who had zero or negative values set to zero. To account for the spike which occurs at zero for the non-positive values that were set to one prior to transforming the values in to log form, we include an indicator variable. Due to space constraints, we have omitted this variable (and the corresponding one for income) from the tables below. An individual has to have valid data for

\footnotetext{
${ }^{3}$ Following the 1997 survey year, the PSID continued with data collection every other year. Therefore, the 19992007 survey years include five waves (1999, 2001, 2003, 2005, and 2007).
} 
each of the waves in which wealth was recorded to be included in the analysis. Additionally, we present estimates of the likelihood of an individual facing fiscal insolvency with an outcome variable for wealth and wealth with home equity coded " 1 " if the net worth dips below zero. Finally, we ran analysis of the likelihood of declaring bankruptcy, based on a variable that that indicated bankruptcy filing between 1984 and 1996. Results for this last specification were not significant, and thus these results are not shown, though we address the possible reasons why in our discussion section.

If we were concerned with aggregate wealth levels, then the selection of certain years would be critical to our estimations given their potential association with different points in the business cycle. However, since we are not interested in comparing overall levels, but in comparing patterns of change within persons and families across two time periods as they relate to health, we think these cyclical concerns are less troubling. To address this possibility, we include survey year indicator variables to account for the potential presence of any specific idiosyncrasies in each wave.

Table 1 below outlines the descriptive statistics of the intra-generational and intergenerational samples by race. The key right hand side variables for our regressions include age, family marital status, family income, amount inherited, unemployment status, health insurance coverage, incidence of acute health shock, incidence of chronic health concern. Additionally, in the intergenerational sample we include parents' family measures for the variables listed above, plus parental wealth. We outline these variables below.

Logged Family Income: The PSID codes income at the family level. In order to account for any potential idiosyncratic fluctuations in family income, we smooth the income variable to represent a five-year average leading up to each wave of the data in this analysis and present its 
natural logarithm. We include a first-difference of family income in the regression equations to examine the relationship between change in income and change in wealth. We present income 2009 dollars.

Logged Inheritance: The PSID also presents data on monetary gifts or inheritances for each survey year. We include the natural logarithm of all of the amounts inherited across each of the waves and include the amount in 2009 dollars in each first-difference regression equation.

Unemployment: We recoded the variables for head and wife employment status to create first-difference unemployment variables. These variables are coded "1" if the head or wife has a spell of unemployment within the five- or two-year periods which mark the collection of wealth data.

Health Insurance Coverage: The PSID codes health insurance status for the years of 1999, 2001, 2003, 2005 and 2007 in two manners. For the family data file, surveyors asked if anyone in the unit was currently covered by health insurance. In the individual data file, health insurance is coded for each family member, providing a better opportunity to examine the differential effects of health care coverage. To make certain we correctly identified who within the family has health insurance, we use the individual-level data — coded as an indicator variable as to whether each individual member of the household is covered. This variable permits us to examine the effect of health insurance coverage as well as the impact of an interaction between health shocks and insurance status on wealth. While health status has been under-examined with respect to family wealth levels, there is a robust economic literature that views health insurance as a method of precautionary savings (Starr-McCluer 1996; Gruber and Yelowitz 1999) or as a way to access higher quality medical care that would otherwise be unavailable or steeply priced (Nyman 1999). 
Medical Expenses beyond Health Insurance: To account for the potential impacts of outof-pocket medical expenses for all persons living within the household we include three separate variables. First, doctor's expenses comprise cost incurred in any out-of-house medical appointment, including dental visits and outpatient surgery. Hospital expenses cover any inpatient stays in medical facilities, including nursing homes. Finally, expenses from prescription medications also include costs of in-home care. Each value is logged to the base e and presented in 2009 dollars.

Acute Health Shock and Chronic Health Condition': In the last five published waves of data the PSID codes for the incidence of thirteen health conditions for the head and wife. Included in these data is a variable which states the age at which the condition first occurred. We match the age of the head (or wife) over the course of each of our waves to the age at which each health condition first became noted by the respondent. To differentiate between severe and acute shocks to health and the onset of chronic health conditions we create two variables. The indicator variable for an acute health shock includes the occurrence of a stroke, heart attack or cancer. We include asthma, arthritis, diabetes, heart disease, high blood pressure, learning disabilities, lung disease, memory loss, psychiatric disorders and "other" chronic illnesses in the indicator (a PSID-created miscellaneous category) for chronic health conditions. Each of these indicator variables are coded "1" if the head or wife suffered from an occurrence of an acute or chronic illness over the course of each wave. Unfortunately the PSID does not permit us to determine precise dates in which chronic illnesses onset and relieve for each individual. Due to this restriction and the assumption that chronic illnesses generally last beyond the course of one

\footnotetext{
${ }^{4} \mathrm{We}$ also coded self-reported health and hospitalization in a variable to note poor health of head and wife. However, we chose to use the incidence of acute illness and the onset of chronic disease as these variables provide a tiered effect to the study of health and wealth and also largely subsume the self-reports of health.
} 
year, we code each year as "1" following the initial onset of a chronic illness for the head or wife.

Given our first-differences methodology (outlined below), indicators for gender and race are de-facto factored out. Noticeably absent from our list of input variables, however, are measures of education. We chose to omit these variables from the first-differences equations due to issues regarding what a change in level of education might mean in the short-term period of two to five years (the length of time between each wave). First, if education remains constant over each wave (i.e. the respondent has completed his or her formal education) then the measure for years of schooling will drop out of the first-differences equation. However, if the respondent continues his or her education in adulthood (through graduate studies or returning to school after a period in the labor force), issues arise as to what the change in years of education means regarding levels of wealth. Researchers commonly view education as an investment which holds returns at some point in the future. However, it is unclear with our data at what point those returns will appear. A four-year absence from the labor market in order to increase one's education may coincide with dropping significantly into debt to pay for tuition. As a result, this would show that an increase in education corresponds to a decrease in wealth over the course of one wave if the individual were not able to immediately upon graduation reap the benefits from increasing his or her stock in the labor market and regain the lost wealth from tuition. Undoubtedly education correlates with wealth, but given that educational outcomes or inputs are not the purpose of our analyses, we omit them from our first-differences equations.

For the uni-generational analysis, we follow one randomly selected individual who was either the head or wife of the family unit in 1984. Given that our key variables are measured at the family level, we may randomly follow the head or wife without changing the measures of the 
input or output variables. We implement first-differences OLS regression to examine wealth mobility and volatility within a generation. We regress the change in logged wealth across one wave of data on the changes in marital status, logged family income, logged inheritance, unemployment, health insurance coverage and health status across the same wave $\mathrm{s}^{5}$.

The bi-generational analysis implements first-differences OLS regressions to analyze the association between parents' levels of wealth, unemployment and health with adult children's levels of family wealth. All members of this sample created their own family by splitting off of the parental household sometime prior to the 2007 survey wave. We regress the change in logged wealth across one wave of data on the changes in age, marital status, logged family income, logged inheritance, unemployment, and health status across the same wave. Additionally, we include input variables to mark changes in the respondents' parents' marital status, wealth, family income, inheritance, unemployment, and health status to determine the impact that life changes for parents hold on the wealth volatility of adult children ${ }^{6}$.

\section{Results}

Models 1 through 5 in Table 2 present the results for the first-differences OLS regression of change in logged non-home equity wealth in 2009 dollars on key input variables in the intragenerational sample. The full regression equation is shown in Model 3, with the event of marriage increasing logged non-home equity wealth and a period of unemployment and the loss of health insurance decreasing logged non-home equity wealth. Models 4 and 5 break the sample into black and white families, respectively. The event of marriage positively impacts the

\footnotetext{
${ }^{5}$ Although omitted from the final tables below, we also include indicator variables for each survey year.

${ }^{6}$ Although not indicated on the tables for the intergenerational analysis, we include indicator variables for each wave of data and an indicator given a value of 1 when the parents of the respondent die, to soak of the variance created from a sudden drop in parental values.
} 
non-home equity wealth for black families, but not families headed by a white individual.

Change in health status or logged medical expenses do not prove significant in impacting change in non-home wealth.

The subsequent models in Table 2 present the results regarding logged wealth with home equity. Model 6 shows that, for the full sample, marriage increases logged wealth including home equity, while losing one's job significantly decreases this measure of wealth. For families headed by black individuals, the findings for marriage remain the same as in the full sample. However, splitting the sample on race shows that white families are disproportionately affected by loss of a job for the head or wife. Although none of the health-related variables play a significant role in models 1 through 7, logged expenses on visits to the doctor, outpatient surgery and dental bills positively relates to logged wealth including home equity for white families. While such a finding potentially holds various interpretations, the elective nature of many outpatient medical procedures may explain this quizzical link between wealth and doctor's expenses.

Table 3 presents the probability of fiscal insolvency excluding and including home equity. Models 1 through 3 present the full sample and break the sample into black and white families. While the full sample regarding fiscal insolvency fails to show significance, we do notice interesting findings when splitting the sample by race. For black families, the event of marriage significantly decreases the chances of falling into debt (excluding home equity) over the same time period. On the other hand, for white families, the onset of an acute illness for a husband or wife significantly increases the chances of fiscal insolvency, excluding home equity. Models 4 through 6 present the probabilities of fiscal insolvency when including home wealth. Here the impact of the onset of an acute illness for the head or wife is significant, 
increasing the likelihood of falling into debt. Interestingly, losing health insurance and change in logged doctor's expenses paid out of pocket decrease the chances of debt over the same time period. As for our interaction variables, the onset of a chronic illness for uninsured heads or wives significantly increases the chance of fiscal insolvency including home equity. Splitting the sample by race shows that the decreased likelihood of debt, including home wealth, in the same wave as loss of insurance holds true only for black families. White families, on the other hand, drive the significance behind the decreased chance of fiscal insolvency with an increase in logged doctor's expenses. Finally, a spell of unemployment and the onset of an acute illness for the head or wife of a white family significantly increase the chances of falling into debt over the same wave of data. The findings here suggest that while the onset of acute illness impacts family wealth, the onset of chronic illnesses lack significance unless the head or wife lacks insurance.

Tables 4 and 5 outline the findings for our intergenerational sample. In the full sample regressions on wealth excluding home equity, getting married, receiving an inheritance, or an increase in logged family doctor's expenses positively impact wealth over the wave for respondents. On the contrary, the loss of a job for a head or a wife significantly decreases wealth excluding home equity over the same period. In the same model, an increase in logged parental wealth, minus home equity, increase in respondent non-home equity wealth, as parents' marriage decreases respondent wealth.

Models 4 and 5 of Table 4 display the results for black and white families respectively. Model 4 shows that marriage and increase in logged inheritance hold a positive impact and unemployment holds a negative impact on logged wealth, excluding home equity, for black families. Additionally, increase in logged parental wealth, excluding home equity, increases wealth for respondents and logged parental inheritance diminishes logged wealth for 
respondents. For white families, the effects of unemployment and inheritance do not prove significant, but the event of marriage positively impacts wealth without home equity over the wave. An increase in logged medical prescription expenses for both the respondents' family and the parents of the respondent also drain logged wealth for white families.

Taking home equity into account in Models 6 through 8 alters some of our findings. The impacts of changes in marriage, and unemployment remain relatively the same for the families in our full sample. However, the logged amount of inheritance no longer proves significant and, interestingly, an increase in logged doctor's fees and the onset of a chronic illness appear to increase logged wealth with home equity included. Also significant in the full sample for wealth with home equity is the finding for parents' chronic illness without insurance. Now significant, chronic illness for parents without insurance appears to drain adult children's wealth, including home equity.

The only differences between the home and non-home equity model for black families is that, when including home equity, parents' loss of employment now affects wealth of the adult children. In comparison, a few differences exist for white families when taking home equity into account. First, spells of unemployment do not appear to impact home equity wealth over the wave. Secondly, the effect of parents' logged doctor's fees disappears, while logged family doctor's fees for white adult children increases logged wealth with home equity. Finally, for parents of adult children, the onset of an acute illness while uninsured decreases home equity wealth for respondents in the same wave.

Table 5 measures the likelihood of fiscal insolvency for the full sample and broken into racial categories. When using the measure of wealth which excludes home equity, we find that marriage decreases the likelihood of falling into debt. Breaking the sample down by race, 
however, we see that this finding only holds true for white families. Models 2 and 3 also display the impact of the parents of adult children for black and white families, respectively. For black families, the onset of a chronic illness for a parent significantly increases the likelihood that their adult children will face fiscal insolvency, excluding home equity. These effects do not appear for white families. However, an increase in logged doctor's expenses for parents increases the likelihood that the adult children in white families will fall into debt, excluding home equity.

Finally, Models 4 through 6 measure the likelihood of fiscal insolvency including home equity. Similar patterns emerge when taking home equity into account, with the exception of a few points of significance. In our full sample, a spell of unemployment now significantly increases the chance of fiscal insolvency. For black families in this model we see the additional effects of marriage decreasing likelihood and unemployment of the head or wife increasing the likelihood of falling into debt over the same wave. For white families, parents' doctor's expenses no longer impact the probability of facing fiscal insolvency, including home equity, over the wave. In addition to maintaining the findings on marriage in the non-home equity regression, we also see the added significance of an increase in family income decreasing the likelihood of falling into debt over the same time period for white families when we add home equity to the measure for wealth.

\section{Discussion}

An extensive literature has documented a robust correlation between socioeconomic status - measured in a variety of ways - and health outcomes; however, much uncertainty remains regarding what causal processes underlie this association. The present paper builds on a growing literature that seeks to better document how and why wealth and SES are related. 
Specifically, we ask the extent to which health shocks affect net worth — a less-studied dimension of socioeconomic status. Given a lack of instruments that meet the exclusion restriction, we used data from the Panel Study of Income Dynamics to pursue a first-differences identification strategy. We estimated a parameter for acute illnesses (which should have a causal effect on wave-to-wave wealth changes) and compared this coefficient to a counterfactual parameter for the presence of chronic illnesses (which we argue should be less causally related to wealth differences year-to-year). We then interacted these health indicators with insurance status as a further test that the health-wealth relationship is likely causal net of covariates. Additionally, we tested a model that predicted bankruptcy declaration and found no significant results, which may be an artifact of the time span - our time series that included this variable ends long before the credit crisis was beginning (the last year bankruptcy was recorded was 1996). That is, the foreclosure and bankruptcy waves had not crested yet and folks were often still able to draw out equity from their homes through loans over our period of study.

For our analyses which follow the adult cohort, starting at the lowest age of 25 in 1984, we notice that onset of an acute illness and the main effect of losing insurance detrimentally affect wealth. Our findings indicate that the onset of acute illness disproportionately impacts white families, as they face a greater likelihood of falling into fiscal insolvency when home equity is and is not included in our measures of family wealth. Additionally, the onset of a chronic illness for a head or wife without health insurance increases the chances that a family will drop into debt, when including home equity. These findings suggest that while the onset of an acute illness itself impacts wealth for families regardless of insurance status, the onset of chronic illness for a family head holds a similar impact only when the individual is uninsured. The significant finding regarding the impact of insurance status on those suffering from chronic 
illness presents valuable information for policy in light of discussions surrounding preventative care and preexisting conditions in insurance coverage.

Finally, we also make a contribution by estimating intergenerational models where the health, wealth and insurance status of respondents' parents can affect offspring net worth. Results indicate that parental medical expenses and chronic illness for uninsured parents present a drain on adult children. Although the onset of a chronic illness for parents disproportionately impacts the adult children of black families, it appears from our data that white families take on more of a burden in terms of parental health with doctors' fees and chronic illness when the parents lack insurance. These findings highlight that interactions between health and insurance status stretch beyond one generation, potentially playing a greater role in cross-generational wealth mobility than previously studied.

Though our data cover a unique period of rising housing prices, they may have implications going forward into the era of health insurance system reform. In fact, health care costs have only risen and credit has only tightened since 2007. Rising health care costs probably mean that the parameter estimates of the effect of health shocks on net worth shown here are too conservative. However, during the time since our data series ended credit has tightened and aggregate net worth has fallen dramatically. The implications of these changes are less clear. Tighter credit and non-health related drops in asset values may suggest that the wealth elasticity of chronic illness has attenuated. However, the effects for bankruptcy or dropping into negative net worth may have increased.

Lastly, though we estimate the interaction of health insurance status and illness in a partial equilibrium framework, if these estimates are extrapolated to the general equilibrium condition - a big "if" - we may expect that quasi-universal health care coverage may lead to 
more stable family nest eggs. Of course, those families who are now forced to buy health insurance may save less as a result, so further analysis is warranted with more recent data along with real-time data as the law's provisions unfold over the next few years. The present analysis suggests that such forward-looking analysis should take an intergenerational framework, since health and health expenses appear to be a salient part of the intergenerational system of wealth stratification in the United States. 


\section{Work Cited}

Averett, Susan, and Sanders Korenman. 1996. "The Economic Reality of the Beauty Myth." Journal of Human Resources 31: 304-330.

Coile, Courtney and Kevin Milligan. 2009. "How Household Portfolios Evolve after Retirement: The Effect of Aging and Health Shocks," Review of Income and Wealth, 55(2): 226-248.

Conley, Dalton. 2001. "Capital for College: Wealth and Post-Secondary Schooling." Sociology of Education. 74:59-73.

Conley, Dalton and Neil G. Bennett. 2000. "Is Biology Destiny? Birth Weight and Life Chances.” American Sociological Review. 65:458-467.

Conley, D., K.M. Pfeiffer, and M. Velez. 2006. Explaining Sibling Differences in Achievement and Behavioral Outcomes: The Importance of Within- and Between-Family Factors. Social Science Research. 56: 1087-1104.

Conley, Dalton, Kate Strully and Neil G. Bennett. 2003. The Starting Gate: Birth Weight and Life Chances. Berkeley, CA: University of California Press.

Conley, D. and R. Glauber. 2006. Gender, Body Mass and Socioeconomic Status: New Evidence from the PSID. Advances in Health Economics and Health Services Research. 17:255-280.

Gruber, Jonathan and Aaron Yelowitz. 1999. "Public health insurance and private saving." Journal of Political Economy. 107: 1249-1274.

Jackson, Margot I. 2009. Understanding Links between Adolescent Health and Educational Attainment. Demography, Volume 46-Number 4: 671-694.

Lleras-Muney, Adriana. 2005. "The Relationship between Education and Adult Mortality in the United States," Review of Economic Studies,.72: .

Meer, Jonathan \& Miller, Douglas L. \& Rosen, Harvey S., 2003. "Exploring the health-wealth nexus" Journal of Health Economics. 22: 713-730.

Nyman, John. 1999. "The value of health insurance: the access motive." Journal of Health Economics. 18:141-152

Poterba, James M., Steven V. Venti and David A. Wise. 2010. "The Asset Cost of Poor Health." NBER Working Paper No. 16389. Cambridge, MA: National Bureau of Economic Statistics.

Rappaport, Elizabeth B. and Jessica M. Robbins. 2005. "Overweight in Southeastern Pennsylvania Children: 2002 Household Health Survey Data.” Public Health Reports, 120:525531. 
Ruhm, Christopher J. 2000. Are Recessions Good for Your Health? Quarterly Journal of Economics. 115:617-650

Smith, James P. 2004. "Unraveling the SES-Health Connection," Population and Development Review Supplement: Aging, Health and Public Policy, 30:108-132.

Snyder, Stephen E. and William N. Evans. "The Effect Of Income On Mortality: Evidence from The Social Security Notch," Review of Economics and Statistics. 2006: 482-495.

Starr-McCluer, Martha. 1996. "Health Insurance and Precautionary Savings." American Economic Review. 86: 285-295.

Yeung, W. Jean and Conley, D. 2008. Black-white Achievement Gap and Family Wealth. Child Development. 79(2):303-324. 


\begin{tabular}{|c|c|c|c|c|c|c|}
\hline & \multicolumn{3}{|c|}{ Intra-Generational Sample } & \multicolumn{3}{|c|}{ Intergenerational Sample } \\
\hline & Total & Black & White & Total & Black & White \\
\hline $\begin{array}{l}1984 \text { Variables } \\
\text { Age }\end{array}$ & $\begin{array}{l}33.90 \\
(5.74)\end{array}$ & $\begin{array}{l}32.57 \\
(5.75)\end{array}$ & $\begin{array}{l}34.05 \\
(5.72)\end{array}$ & $\begin{array}{l}11.73 \\
(5.39)\end{array}$ & $\begin{array}{l}11.63 \\
(5.16)\end{array}$ & $\begin{array}{l}11.74 \\
(5.42)\end{array}$ \\
\hline Married & $\begin{array}{l}0.70 \\
(0.46)\end{array}$ & $\begin{array}{l}0.42 \\
(0.49)\end{array}$ & $\begin{array}{l}0.73 \\
(0.45)\end{array}$ & $\begin{array}{l}0.84 \\
(0.37)\end{array}$ & $\begin{array}{l}0.49 \\
(0.50)\end{array}$ & $\begin{array}{l}0.88 \\
(0.33)\end{array}$ \\
\hline Wealth & $\begin{array}{l}118,878 \\
(708,795)\end{array}$ & $\begin{array}{l}14,556 \\
(32,762)\end{array}$ & $\begin{array}{l}130,274 \\
(745,653)\end{array}$ & $\begin{array}{c}188,911 \\
(847,536)\end{array}$ & $\begin{array}{l}19,282 \\
(50,091)\end{array}$ & $\begin{array}{c}208,519 \\
(893,050)\end{array}$ \\
\hline Median Wealth & 20,661 & 4,132 & 23,760 & 27,893 & 3,202 & 33,471 \\
\hline Wealth Home & $\begin{array}{l}170,187 \\
(730,866)\end{array}$ & $\begin{array}{l}27,820 \\
(47,217)\end{array}$ & $\begin{array}{l}185,738 \\
(768,108)\end{array}$ & $\begin{array}{c}271,521 \\
(874,796)\end{array}$ & $\begin{array}{l}40,427 \\
(78,531)\end{array}$ & $\begin{array}{c}298,235 \\
(919,960)\end{array}$ \\
\hline Median Wealth Home & 61,415 & 7,025 & 68,182 & 102,686 & 10,331 & 115,703 \\
\hline Family Income & $\begin{array}{c}70,237 \\
(47,251)\end{array}$ & $\begin{array}{l}40,934 \\
(23,679)\end{array}$ & $\begin{array}{c}73,438 \\
(48,083)\end{array}$ & $\begin{array}{l}80,127 \\
(58,183)\end{array}$ & $\begin{array}{l}38,953 \\
(26,284)\end{array}$ & $\begin{array}{l}84,886 \\
(58,983)\end{array}$ \\
\hline Education of Head & $\begin{array}{l}13.36 \\
(2.21)\end{array}$ & $\begin{array}{l}12.35 \\
(2.03)\end{array}$ & $\begin{array}{l}13.47 \\
(2.20)\end{array}$ & $\begin{array}{l}13.34 \\
(2.36)\end{array}$ & $\begin{array}{l}11.56 \\
(2.53)\end{array}$ & $\begin{array}{l}13.55 \\
(2.25)\end{array}$ \\
\hline Number of Cases & 1,811 & 516 & 1,295 & 1,982 & 642 & 1,340 \\
\hline \multicolumn{7}{|l|}{2007 Variables } \\
\hline Age & $\begin{array}{l}56.76 \\
(5.77)\end{array}$ & $\begin{array}{l}55.54 \\
(5.70)\end{array}$ & $\begin{array}{l}56.92 \\
(5.76)\end{array}$ & $\begin{array}{l}34.86 \\
(5.41)\end{array}$ & $\begin{array}{l}34.73 \\
(5.27)\end{array}$ & $\begin{array}{l}34.88 \\
(5.43)\end{array}$ \\
\hline Married & $\begin{array}{l}0.66 \\
(0.48)\end{array}$ & $\begin{array}{l}0.36 \\
(0.48)\end{array}$ & $\begin{array}{l}0.70 \\
(0.46)\end{array}$ & $\begin{array}{l}0.69 \\
(0.46)\end{array}$ & $\begin{array}{l}0.42 \\
(0.49)\end{array}$ & $\begin{array}{l}0.73 \\
(0.44)\end{array}$ \\
\hline $\begin{array}{l}\text { \% Inherited } \\
1984-2007\end{array}$ & $\begin{array}{l}0.46 \\
(0.50)\end{array}$ & $\begin{array}{l}0.22 \\
(0.41)\end{array}$ & $\begin{array}{l}0.50 \\
(0.50)\end{array}$ & $\begin{array}{l}0.24 \\
(0.43)\end{array}$ & $\begin{array}{l}0.13 \\
(0.34)\end{array}$ & $\begin{array}{l}0.26 \\
(0.44)\end{array}$ \\
\hline Amount Inherited & $\begin{array}{c}5,342 \\
(22,408)\end{array}$ & $\begin{array}{c}577 \\
(2,203)\end{array}$ & $\begin{array}{c}5,987 \\
(23,792)\end{array}$ & $\begin{array}{c}505 \\
(3,522)\end{array}$ & $\begin{array}{c}133 \\
(2,360)\end{array}$ & $\begin{array}{c}555 \\
(3,649)\end{array}$ \\
\hline Median Inheritance & 0 & 0 & 87 & 0 & 0 & 0 \\
\hline Wealth & $\begin{array}{c}496,266 \\
(1,867,284)\end{array}$ & $\begin{array}{c}57,167 \\
(207,052)\end{array}$ & $\begin{array}{c}555,690 \\
(1,980,998)\end{array}$ & $\begin{array}{c}123,769 \\
(637,667)\end{array}$ & $\begin{array}{c}58,049 \\
(263,962)\end{array}$ & $\begin{array}{c}132,738 \\
(672,349)\end{array}$ \\
\hline Median Wealth & 98,344 & 7,039 & 121,222 & 17,391 & 4,244 & 21,222 \\
\hline Wealth Home & $\begin{array}{c}669,372 \\
(2,033,309)\end{array}$ & $\begin{array}{c}113,822 \\
(254,704)\end{array}$ & $\begin{array}{c}744,554 \\
(2,153,839)\end{array}$ & $\begin{array}{c}205,310 \\
(696,512)\end{array}$ & $\begin{array}{c}87,241 \\
(296,340)\end{array}$ & $\begin{array}{c}221,423 \\
(733,029)\end{array}$ \\
\hline Median Wealth Home & 242,236 & 41,408 & 288,820 & 51,760 & 10,352 & 65,735 \\
\hline Family Income & $\begin{array}{c}105,089 \\
(154,916)\end{array}$ & $\begin{array}{l}53,328 \\
(40,262)\end{array}$ & $\begin{array}{l}112,094 \\
(163,168)\end{array}$ & $\begin{array}{l}86,275 \\
(74,211)\end{array}$ & $\begin{array}{l}51,948 \\
(38,663)\end{array}$ & $\begin{array}{c}90,960 \\
(76,640)\end{array}$ \\
\hline Education of Head & $\begin{array}{l}13.68 \\
(2.35)\end{array}$ & $\begin{array}{l}12.75 \\
(2.61)\end{array}$ & $\begin{array}{l}13.81 \\
(2.28)\end{array}$ & $\begin{array}{l}13.76 \\
(2.37)\end{array}$ & $\begin{array}{l}12.92 \\
(2.15)\end{array}$ & $\begin{array}{l}13.88 \\
(2.38)\end{array}$ \\
\hline Number of Cases & 1,811 & 516 & 1,295 & 1,982 & 642 & 1,340 \\
\hline
\end{tabular}

Note: Standard deviations in parenthesis. All monetary values reported in 2009 dollars. Intra-generational sample restricted to ages 25 45 in 1984 and 48-68 in 2007. Intergenerational sample restricted to ages 3-21 in 1984 and 26-44 in 2007. Parental marital status, wealth, income and education are represented in the 1984 intergenerational sample statistics. 


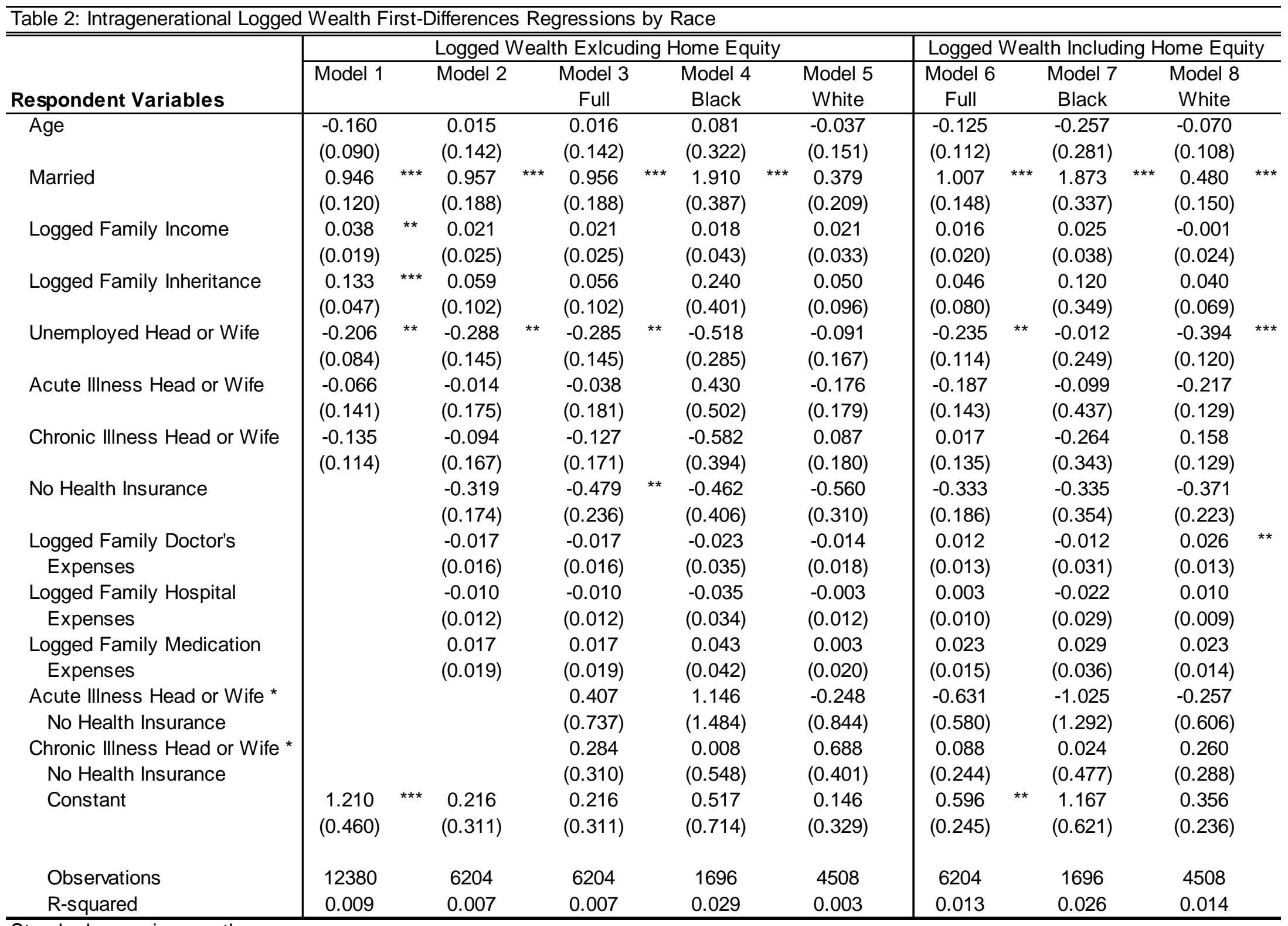

Standard errors in parentheses

*** $p<0.01,{ }^{\star *} p<0.05$ 


\begin{tabular}{|c|c|c|c|c|c|c|c|c|c|c|c|}
\hline \multirow[b]{2}{*}{ Respondent Variables } & \multicolumn{5}{|c|}{$\begin{array}{l}\text { Probability of Fiscal Insolvency } \\
\text { Excluding Home Equity }\end{array}$} & \multicolumn{6}{|c|}{$\begin{array}{c}\text { Probability of Fiscal Insolvency Including } \\
\text { Home Equity }\end{array}$} \\
\hline & $\begin{array}{l}\text { Model } 1 \\
\text { Full }\end{array}$ & $\begin{array}{l}\text { Model } 2 \\
\text { Black }\end{array}$ & & $\begin{array}{l}\text { Model } 3 \\
\text { White }\end{array}$ & & \begin{tabular}{|c|} 
Model 4 \\
Full \\
\end{tabular} & & $\begin{array}{l}\text { Model } 5 \\
\text { Black }\end{array}$ & & $\begin{array}{l}\text { Model } 6 \\
\text { White }\end{array}$ & \\
\hline Age & $\begin{array}{l}-0.009 \\
(0.013)\end{array}$ & $\begin{array}{l}-0.027 \\
(0.031)\end{array}$ & & $\begin{array}{c}0.001 \\
(0.014)\end{array}$ & & $\begin{array}{l}-0.003 \\
(0.010)\end{array}$ & & $\begin{array}{l}-0.010 \\
(0.025)\end{array}$ & & $\begin{array}{c}0.001 \\
(0.010)\end{array}$ & \\
\hline Married & $\begin{array}{l}-0.023 \\
(0.018)\end{array}$ & $\begin{array}{l}-0.077 \\
(0.038)\end{array}$ & $\star \star$ & $\begin{array}{l}0.010 \\
(0.019)\end{array}$ & & $\begin{array}{l}-0.009 \\
(0.013)\end{array}$ & & $\begin{array}{l}-0.046 \\
(0.030)\end{array}$ & & $\begin{array}{c}0.013 \\
(0.014)\end{array}$ & \\
\hline Logged Family Income & $\begin{array}{l}-0.002 \\
(0.002)\end{array}$ & $\begin{array}{l}-0.002 \\
(0.004)\end{array}$ & & $\begin{array}{l}-0.002 \\
(0.003)\end{array}$ & & $\begin{array}{c}0.001 \\
(0.002)\end{array}$ & & $\begin{array}{l}-0.001 \\
(0.003)\end{array}$ & & $\begin{array}{c}0.003 \\
(0.002)\end{array}$ & \\
\hline Logged Family Inheritance & $\begin{array}{l}-0.004 \\
(0.010)\end{array}$ & $\begin{array}{l}-0.021 \\
(0.039)\end{array}$ & & $\begin{array}{l}-0.004 \\
(0.009)\end{array}$ & & $\begin{array}{l}-0.003 \\
(0.007)\end{array}$ & & $\begin{array}{l}-0.008 \\
(0.031)\end{array}$ & & $\begin{array}{l}-0.002 \\
(0.006)\end{array}$ & \\
\hline Unemployed Head or Wife & $\begin{array}{l}0.018 \\
(0.014)\end{array}$ & $\begin{array}{l}0.048 \\
(0.028)\end{array}$ & & $\begin{array}{l}-0.004 \\
(0.015)\end{array}$ & & $\begin{array}{l}0.018 \\
(0.010)\end{array}$ & & $\begin{array}{l}0.000 \\
(0.022)\end{array}$ & & $\begin{array}{c}0.031 \\
(0.011)\end{array}$ & *** \\
\hline Acute Illness Head or Wife & $\begin{array}{c}0.030 \\
(0.017)\end{array}$ & $\begin{array}{c}0.000 \\
(0.049)\end{array}$ & & $\begin{array}{l}0.040 \\
(0.017)\end{array}$ & ** & $\begin{array}{c}0.032 \\
(0.013)\end{array}$ & ** & $\begin{array}{c}0.034 \\
(0.039)\end{array}$ & & $\begin{array}{c}0.033 \\
(0.012)\end{array}$ & 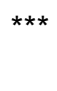 \\
\hline Chronic Illness Head or Wife & $\begin{array}{c}0.020 \\
(0.016)\end{array}$ & $\begin{array}{l}0.067 \\
(0.038)\end{array}$ & & $\begin{array}{l}-0.001 \\
(0.017)\end{array}$ & & $\begin{array}{c}0.000 \\
(0.012)\end{array}$ & & $\begin{array}{c}0.031 \\
(0.031)\end{array}$ & & $\begin{array}{l}-0.014 \\
(0.012)\end{array}$ & \\
\hline No Health Insurance & $\begin{array}{l}-0.028 \\
(0.022)\end{array}$ & $\begin{array}{l}-0.044 \\
(0.040)\end{array}$ & & $\begin{array}{l}-0.005 \\
(0.029)\end{array}$ & & $\begin{array}{l}-0.035 \\
(0.017)\end{array}$ & $\star *$ & $\begin{array}{l}-0.062 \\
(0.032)\end{array}$ & $\star \star$ & $\begin{array}{c}0.005 \\
(0.020)\end{array}$ & \\
\hline $\begin{array}{l}\text { Logged Family Doctor's } \\
\text { Expenses }\end{array}$ & $\begin{array}{c}0.003 \\
(0.002)\end{array}$ & $\begin{array}{c}0.003 \\
(0.003)\end{array}$ & & $\begin{array}{c}0.003 \\
(0.002)\end{array}$ & & $\begin{array}{l}-0.003 \\
(0.001)\end{array}$ & $\star \star$ & $\begin{array}{l}-0.003 \\
(0.003)\end{array}$ & & $\begin{array}{l}-0.003 \\
(0.001)\end{array}$ & $\star *$ \\
\hline $\begin{array}{l}\text { Logged Family Hospital } \\
\text { Expenses }\end{array}$ & $\begin{array}{c}0.000 \\
(0.001)\end{array}$ & $\begin{array}{c}0.001 \\
(0.003)\end{array}$ & & $\begin{array}{l}0.000 \\
(0.001)\end{array}$ & & $\begin{array}{c}0.000 \\
(0.001)\end{array}$ & & $\begin{array}{l}0.003 \\
(0.003)\end{array}$ & & $\begin{array}{l}-0.001 \\
(0.001)\end{array}$ & \\
\hline $\begin{array}{l}\text { Logged Family Medication } \\
\text { Expenses }\end{array}$ & $\begin{array}{l}0.001 \\
(0.002)\end{array}$ & $\begin{array}{l}0.000 \\
(0.004)\end{array}$ & & $\begin{array}{c}0.002 \\
(0.002)\end{array}$ & & $\begin{array}{l}-0.001 \\
(0.001)\end{array}$ & & $\begin{array}{l}-0.002 \\
(0.003)\end{array}$ & & $\begin{array}{c}0.000 \\
(0.001)\end{array}$ & \\
\hline $\begin{array}{l}\text { Acute Illness Head or Wife * } \\
\text { No Health Insurance }\end{array}$ & $\begin{array}{l}-0.038 \\
(0.069)\end{array}$ & $\begin{array}{l}-0.010 \\
(0.144)\end{array}$ & & $\begin{array}{l}-0.046 \\
(0.078)\end{array}$ & & $\begin{array}{l}-0.031 \\
(0.052)\end{array}$ & & $\begin{array}{l}-0.024 \\
(0.115)\end{array}$ & & $\begin{array}{l}-0.043 \\
(0.054)\end{array}$ & \\
\hline $\begin{array}{l}\text { Chronic Illness Head or Wife * } \\
\text { No Health Insurance } \\
\text { Constant }\end{array}$ & $\begin{array}{c}0.032 \\
(0.029) \\
0.005 \\
(0.029)\end{array}$ & $\begin{array}{c}0.033 \\
(0.053) \\
0.025 \\
(0.069)\end{array}$ & & $\begin{array}{l}0.016 \\
(0.037) \\
-0.008 \\
(0.030)\end{array}$ & & $\begin{array}{l}0.044 \\
(0.022) \\
-0.008 \\
(0.022)\end{array}$ & ** & $\begin{array}{c}0.041 \\
(0.043) \\
0.006 \\
(0.055)\end{array}$ & & $\begin{array}{l}0.028 \\
(0.026) \\
-0.016 \\
(0.021)\end{array}$ & \\
\hline Observations & 6204 & 1696 & & 4508 & & 6204 & & 1696 & & 4508 & \\
\hline R-squared & 0.003 & 0.011 & & 0.003 & & 0.005 & & 0.009 & & 0.011 & \\
\hline
\end{tabular}

Standard errors in parentheses

*** $p<0.01$, ** $p<0.05$ 


\begin{tabular}{|c|c|c|c|c|c|c|c|c|c|c|c|c|c|c|c|c|}
\hline \multirow[b]{2}{*}{ Respondent Variables } & \multicolumn{10}{|c|}{ Logged Wealth Exlcuding Home Equity } & \multicolumn{6}{|c|}{ Logged Wealth Including Home Equity } \\
\hline & Model 1 & & Model 2 & & $\begin{array}{c}\text { Model } 3 \\
\text { Full }\end{array}$ & & $\begin{array}{c}\text { Model } 4 \\
\text { Black }\end{array}$ & & $\begin{array}{l}\text { Model } 5 \\
\text { White }\end{array}$ & & $\begin{array}{c}\text { Model } 6 \\
\text { Full }\end{array}$ & & $\begin{array}{c}\text { Model } 7 \\
\text { Black }\end{array}$ & & $\begin{array}{l}\text { Model } 8 \\
\text { White }\end{array}$ & \\
\hline Age & $\begin{array}{l}-0.040 \\
(0.140)\end{array}$ & & $\begin{array}{l}-0.105 \\
(0.163)\end{array}$ & & $\begin{array}{l}-0.105 \\
(0.163)\end{array}$ & & $\begin{array}{c}-0.263 \\
(0.302)\end{array}$ & & $\begin{array}{c}-0.032 \\
(0.194)\end{array}$ & & $\begin{array}{c}-0.007 \\
(0.152)\end{array}$ & & $\begin{array}{c}-0.083 \\
(0.291)\end{array}$ & & $\begin{array}{c}0.038 \\
(0.177)\end{array}$ & \\
\hline Married & $\begin{array}{c}0.874 \\
(0.133)\end{array}$ & *** & $\begin{array}{c}1.099 \\
(0.155)\end{array}$ & *** & $\begin{array}{c}1.099 \\
(0.155)\end{array}$ & 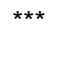 & $\begin{array}{c}1.465 \\
(0.280)\end{array}$ & 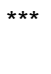 & $\begin{array}{c}0.936 \\
(0.187)\end{array}$ & $\star \star \star *$ & $\begin{array}{c}1.336 \\
(0.144)\end{array}$ & $\star \star \star *$ & $\begin{array}{c}1.678 \\
(0.270)\end{array}$ & $\star \star \star *$ & $\begin{array}{c}1.175 \\
(0.170)\end{array}$ & 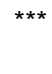 \\
\hline Logged Family Income & $\begin{array}{c}0.021 \\
(0.025)\end{array}$ & & $\begin{array}{c}0.020 \\
(0.029)\end{array}$ & & $\begin{array}{c}0.020 \\
(0.029)\end{array}$ & & $\begin{array}{l}-0.039 \\
(0.041)\end{array}$ & & $\begin{array}{c}0.076 \\
(0.044)\end{array}$ & & $\begin{array}{c}0.034 \\
(0.027)\end{array}$ & & $\begin{array}{l}-0.016 \\
(0.039)\end{array}$ & & $\begin{array}{c}0.084 \\
(0.040)\end{array}$ & ** \\
\hline Logged Family Inheritance & $\begin{array}{c}0.352 \\
(0.158)\end{array}$ & ** & $\begin{array}{c}0.516 \\
(0.204)\end{array}$ & $\star \star$ & $\begin{array}{c}0.518 \\
(0.204)\end{array}$ & $\star \star$ & $\begin{array}{c}1.566 \\
(0.652)\end{array}$ & ** & $\begin{array}{c}0.385 \\
(0.212)\end{array}$ & & $\begin{array}{c}0.254 \\
(0.190)\end{array}$ & & $\begin{array}{c}1.692 \\
(0.629)\end{array}$ & $\star \star \star *$ & $\begin{array}{c}0.091 \\
(0.193)\end{array}$ & \\
\hline Unemployed Head or Wife & $\begin{array}{l}-0.454 \\
(0.127)\end{array}$ & *** & $\begin{array}{l}-0.406 \\
(0.153)\end{array}$ & *** & $\begin{array}{l}-0.409 \\
(0.153)\end{array}$ & $\star \star \star *$ & $\begin{array}{l}-0.714 \\
(0.240)\end{array}$ & $\star \star \star ~$ & $\begin{array}{l}-0.115 \\
(0.204)\end{array}$ & & $\begin{array}{l}-0.431 \\
(0.143)\end{array}$ & $\star \star \star *$ & $\begin{array}{l}-0.657 \\
(0.232)\end{array}$ & 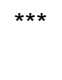 & $\begin{array}{l}-0.204 \\
(0.186)\end{array}$ & \\
\hline Acute Illness Head or Wife & $\begin{array}{l}-0.406 \\
(0.420)\end{array}$ & & $\begin{array}{l}-0.460 \\
(0.472)\end{array}$ & & $\begin{array}{l}-0.472 \\
(0.499)\end{array}$ & & $\begin{array}{l}-1.047 \\
(1.102)\end{array}$ & & $\begin{array}{l}-0.192 \\
(0.555)\end{array}$ & & $\begin{array}{c}0.003 \\
(0.464)\end{array}$ & & $\begin{array}{l}-0.561 \\
(1.063)\end{array}$ & & $\begin{array}{c}0.250 \\
(0.505)\end{array}$ & \\
\hline Chronic Illness Head or Wife & $\begin{array}{c}0.309 \\
(0.195)\end{array}$ & & $\begin{array}{c}0.244 \\
(0.225)\end{array}$ & & $\begin{array}{c}0.225 \\
(0.232)\end{array}$ & & $\begin{array}{c}0.531 \\
(0.449)\end{array}$ & & $\begin{array}{c}0.073 \\
(0.272)\end{array}$ & & $\begin{array}{c}0.565 \\
(0.216)\end{array}$ & $\star \star \star *$ & $\begin{array}{c}0.652 \\
(0.433)\end{array}$ & & $\begin{array}{c}0.470 \\
(0.248)\end{array}$ & \\
\hline No Health Insurance & & & $\begin{array}{l}-0.175 \\
(0.165)\end{array}$ & & $\begin{array}{l}-0.194 \\
(0.187)\end{array}$ & & $\begin{array}{l}-0.385 \\
(0.286)\end{array}$ & & $\begin{array}{l}-0.034 \\
(0.254)\end{array}$ & & $\begin{array}{l}-0.285 \\
(0.174)\end{array}$ & & $\begin{array}{l}-0.433 \\
(0.275)\end{array}$ & & $\begin{array}{l}-0.165 \\
(0.232)\end{array}$ & \\
\hline $\begin{array}{l}\text { Logged Family Doctor's } \\
\text { Expenses }\end{array}$ & & & $\begin{array}{c}0.038 \\
(0.019)\end{array}$ & & $\begin{array}{c}0.038 \\
(0.019)\end{array}$ & $\star \star$ & $\begin{array}{l}0.028 \\
(0.036)\end{array}$ & & $\begin{array}{c}0.042 \\
(0.023)\end{array}$ & & $\begin{array}{l}0.056 \\
(0.018)\end{array}$ & $* \star *$ & $\begin{array}{l}0.045 \\
(0.035)\end{array}$ & & $\begin{array}{l}0.062 \\
(0.021)\end{array}$ & $* * *$ \\
\hline $\begin{array}{l}\text { Logged Family Hospital } \\
\text { Expenses }\end{array}$ & & & $\begin{array}{l}-0.018 \\
(0.016)\end{array}$ & & $\begin{array}{l}-0.019 \\
(0.016)\end{array}$ & & $\begin{array}{l}-0.032 \\
(0.037)\end{array}$ & & $\begin{array}{l}-0.019 \\
(0.018)\end{array}$ & & $\begin{array}{l}-0.015 \\
(0.015)\end{array}$ & & $\begin{array}{l}-0.044 \\
(0.036)\end{array}$ & & $\begin{array}{l}-0.012 \\
(0.017)\end{array}$ & \\
\hline $\begin{array}{l}\text { Logged Family Medication } \\
\text { Expenses }\end{array}$ & & & $\begin{array}{l}-0.030 \\
(0.023)\end{array}$ & & $\begin{array}{l}-0.030 \\
(0.023)\end{array}$ & & $\begin{array}{c}0.025 \\
(0.043)\end{array}$ & & $\begin{array}{l}-0.055 \\
(0.027)\end{array}$ & ** & $\begin{array}{l}-0.022 \\
(0.021)\end{array}$ & & $\begin{array}{c}0.010 \\
(0.042)\end{array}$ & & $\begin{array}{l}-0.035 \\
(0.025)\end{array}$ & \\
\hline $\begin{array}{l}\text { Acute Illness Head or Wife * } \\
\text { No Health Insurance }\end{array}$ & & & & & $\begin{array}{c}0.060 \\
(1.539)\end{array}$ & & $\begin{array}{c}1.180 \\
(3.646)\end{array}$ & & $\begin{array}{l}-0.321 \\
(1.676)\end{array}$ & & $\begin{array}{c}1.193 \\
(1.432)\end{array}$ & & $\begin{array}{c}0.825 \\
(3.521)\end{array}$ & & $\begin{array}{l}1.303 \\
(1.526)\end{array}$ & \\
\hline $\begin{array}{l}\text { Chronic Illness Head or Wife * } \\
\text { No Health Insurance }\end{array}$ & & & & & $\begin{array}{c}0.088 \\
(0.352)\end{array}$ & & $\begin{array}{c}0.361 \\
(0.560)\end{array}$ & & $\begin{array}{l}-0.198 \\
(0.469)\end{array}$ & & $\begin{array}{l}-0.145 \\
(0.327)\end{array}$ & & $\begin{array}{c}0.421 \\
(0.540)\end{array}$ & & $\begin{array}{l}-0.632 \\
(0.428)\end{array}$ & \\
\hline Parent Variables & & & & & & & & & & & & & & & & \\
\hline Married & $\begin{array}{l}-0.636 \\
(0.191)\end{array}$ & $\star \star * *$ & $\begin{array}{l}-0.508 \\
(0.223)\end{array}$ & ** & $\begin{array}{l}-0.494 \\
(0.223)\end{array}$ & ** & $\begin{array}{l}-0.543 \\
(0.401)\end{array}$ & & $\begin{array}{l}-0.394 \\
(0.273)\end{array}$ & & $\begin{array}{l}-0.587 \\
(0.208)\end{array}$ & $\star \star \star *$ & $\begin{array}{l}-0.558 \\
(0.387)\end{array}$ & & $\begin{array}{l}-0.547 \\
(0.252)\end{array}$ & ** \\
\hline Logged Family Wealth & $\begin{array}{c}0.083 \\
(0.036)\end{array}$ & $\star \star$ & $\begin{array}{l}0.079 \\
(0.041)\end{array}$ & & $\begin{array}{c}0.082 \\
(0.041)\end{array}$ & $\star *$ & $\begin{array}{c}0.172 \\
(0.068)\end{array}$ & ** & $\begin{array}{c}0.027 \\
(0.055)\end{array}$ & & & & & & & \\
\hline $\begin{array}{l}\text { Logged Family Wealth } \\
\text { With Home Equity }\end{array}$ & & & & & & & & & & & $\begin{array}{c}0.142 \\
(0.048)\end{array}$ & $* * *$ & $\begin{array}{c}0.227 \\
(0.079)\end{array}$ & $* * *$ & $\begin{array}{c}0.093 \\
(0.063)\end{array}$ & \\
\hline Logged Family Income & $\begin{array}{l}-0.174 \\
(0.173)\end{array}$ & & $\begin{array}{l}-0.052 \\
(0.238)\end{array}$ & & $\begin{array}{l}-0.055 \\
(0.238)\end{array}$ & & $\begin{array}{l}-0.299 \\
(0.411)\end{array}$ & & $\begin{array}{c}0.045 \\
(0.294)\end{array}$ & & $\begin{array}{l}-0.216 \\
(0.221)\end{array}$ & & $\begin{array}{l}-0.376 \\
(0.396)\end{array}$ & & $\begin{array}{l}-0.139 \\
(0.268)\end{array}$ & \\
\hline Logged Family Inheritance & $\begin{array}{l}-0.136 \\
(0.109)\end{array}$ & & $\begin{array}{l}-0.126 \\
(0.151)\end{array}$ & & $\begin{array}{l}-0.123 \\
(0.151)\end{array}$ & & $\begin{array}{l}-1.601 \\
(0.641)\end{array}$ & ** & $\begin{array}{l}-0.043 \\
(0.155)\end{array}$ & & $\begin{array}{l}-0.108 \\
(0.140)\end{array}$ & & $\begin{array}{l}-1.658 \\
(0.619)\end{array}$ & $* * *$ & $\begin{array}{l}0.010 \\
(0.141)\end{array}$ & \\
\hline Unemployed Head or Wife & $\begin{array}{c}0.380 \\
(0.197)\end{array}$ & & $\begin{array}{c}0.181 \\
(0.255)\end{array}$ & & $\begin{array}{c}0.176 \\
(0.256)\end{array}$ & & $\begin{array}{c}0.729 \\
(0.432)\end{array}$ & & $\begin{array}{l}-0.131 \\
(0.324)\end{array}$ & & $\begin{array}{c}0.544 \\
(0.238)\end{array}$ & $\star \star$ & $\begin{array}{l}1.050 \\
(0.417)\end{array}$ & $\star \star$ & $\begin{array}{c}0.260 \\
(0.295)\end{array}$ & \\
\hline Acute Illness Head or Wife & $\begin{array}{l}-0.188 \\
(0.196)\end{array}$ & & $\begin{array}{l}-0.031 \\
(0.219)\end{array}$ & & $\begin{array}{l}-0.004 \\
(0.239)\end{array}$ & & $\begin{array}{c}0.253 \\
(0.596)\end{array}$ & & $\begin{array}{l}-0.059 \\
(0.257)\end{array}$ & & $\begin{array}{c}0.024 \\
(0.222)\end{array}$ & & $\begin{array}{c}0.349 \\
(0.575)\end{array}$ & & $\begin{array}{l}-0.051 \\
(0.234)\end{array}$ & \\
\hline Chronic Illness Head or Wife & $\begin{array}{l}-0.134 \\
(0.205)\end{array}$ & & $\begin{array}{l}-0.288 \\
(0.245)\end{array}$ & & $\begin{array}{l}-0.174 \\
(0.260)\end{array}$ & & $\begin{array}{l}-0.850 \\
(0.508)\end{array}$ & & $\begin{array}{c}0.110 \\
(0.302)\end{array}$ & & $\begin{array}{l}-0.173 \\
(0.242)\end{array}$ & & $\begin{array}{l}-0.441 \\
(0.490)\end{array}$ & & $\begin{array}{l}-0.077 \\
(0.275)\end{array}$ & \\
\hline No Health Insurance & & & $\begin{array}{l}-0.132 \\
(0.204)\end{array}$ & & $\begin{array}{c}0.072 \\
(0.258)\end{array}$ & & $\begin{array}{l}0.168 \\
(0.431)\end{array}$ & & $\begin{array}{l}-0.139 \\
(0.333)\end{array}$ & & $\begin{array}{c}0.121 \\
(0.241)\end{array}$ & & $\begin{array}{c}0.261 \\
(0.417)\end{array}$ & & $\begin{array}{l}-0.062 \\
(0.304)\end{array}$ & \\
\hline $\begin{array}{l}\text { Logged Family Doctor's } \\
\text { Expenses }\end{array}$ & & & $\begin{array}{l}-0.030 \\
(0.020)\end{array}$ & & $\begin{array}{l}-0.030 \\
(0.020)\end{array}$ & & $\begin{array}{c}0.027 \\
(0.040)\end{array}$ & & $\begin{array}{l}-0.053 \\
(0.023)\end{array}$ & ** & $\begin{array}{l}-0.008 \\
(0.019)\end{array}$ & & $\begin{array}{c}0.002 \\
(0.039)\end{array}$ & & $\begin{array}{l}-0.011 \\
(0.021)\end{array}$ & \\
\hline $\begin{array}{l}\text { Logged Family Hospital } \\
\text { Expenses }\end{array}$ & & & $\begin{array}{c}0.019 \\
(0.017)\end{array}$ & & $\begin{array}{l}0.018 \\
(0.017)\end{array}$ & & $\begin{array}{c}0.024 \\
(0.040)\end{array}$ & & $\begin{array}{c}0.014 \\
(0.018)\end{array}$ & & $\begin{array}{l}-0.001 \\
(0.016)\end{array}$ & & $\begin{array}{l}0.008 \\
(0.039)\end{array}$ & & $\begin{array}{l}-0.004 \\
(0.017)\end{array}$ & \\
\hline $\begin{array}{l}\text { Logged Family Medication } \\
\text { Expenses }\end{array}$ & & & $\begin{array}{c}0.009 \\
(0.021)\end{array}$ & & $\begin{array}{l}0.010 \\
(0.021)\end{array}$ & & $\begin{array}{l}-0.009 \\
(0.041)\end{array}$ & & $\begin{array}{c}0.018 \\
(0.025)\end{array}$ & & $\begin{array}{l}0.017 \\
(0.020)\end{array}$ & & $\begin{array}{c}0.010 \\
(0.040)\end{array}$ & & $\begin{array}{c}0.020 \\
(0.023)\end{array}$ & \\
\hline $\begin{array}{l}\text { Acute Illness Head or Wife * } \\
\text { No Health Insurance }\end{array}$ & & & & & $\begin{array}{l}-0.150 \\
(0.607)\end{array}$ & & $\begin{array}{c}0.358 \\
(1.320)\end{array}$ & & $\begin{array}{l}-0.307 \\
(0.682)\end{array}$ & & $\begin{array}{l}-0.336 \\
(0.564)\end{array}$ & & $\begin{array}{l}-0.479 \\
(1.265)\end{array}$ & & $\begin{array}{l}-0.289 \\
(0.621)\end{array}$ & \\
\hline $\begin{array}{l}\text { Chronic Illness Head or Wife * } \\
\text { No Health Insurance }\end{array}$ & & & & & $\begin{array}{l}-0.425 \\
(0.339)\end{array}$ & & $\begin{array}{l}-0.361 \\
(0.568)\end{array}$ & & $\begin{array}{l}-0.351 \\
(0.431)\end{array}$ & & $\begin{array}{l}-0.723 \\
(0.315)\end{array}$ & $\star \star$ & $\begin{array}{l}-0.531 \\
(0.548)\end{array}$ & & $\begin{array}{l}-0.819 \\
(0.392)\end{array}$ & $\star \star$ \\
\hline Constant & $\begin{array}{c}0.198 \\
(0.758)\end{array}$ & & $\begin{array}{c}0.253 \\
(0.366)\end{array}$ & & $\begin{array}{c}0.252 \\
(0.366)\end{array}$ & & $\begin{array}{c}0.468 \\
(0.699)\end{array}$ & & $\begin{array}{c}0.174 \\
(0.430)\end{array}$ & & $\begin{array}{c}0.076 \\
(0.340)\end{array}$ & & $\begin{array}{c}0.061 \\
(0.675)\end{array}$ & & $\begin{array}{c}0.088 \\
(0.392)\end{array}$ & \\
\hline Observations & 7808 & & 6000 & & 6000 & & 1893 & & 4107 & & 6000 & & 1893 & & 4107 & \\
\hline R-squared & 0.012 & & 0.015 & & 0.015 & & 0.039 & & 0.013 & & 0.026 & & 0.049 & & 0.023 & \\
\hline
\end{tabular}

Standard errors in parentheses

*** $p<0.01,{ }^{* \star} p<0.05$ 


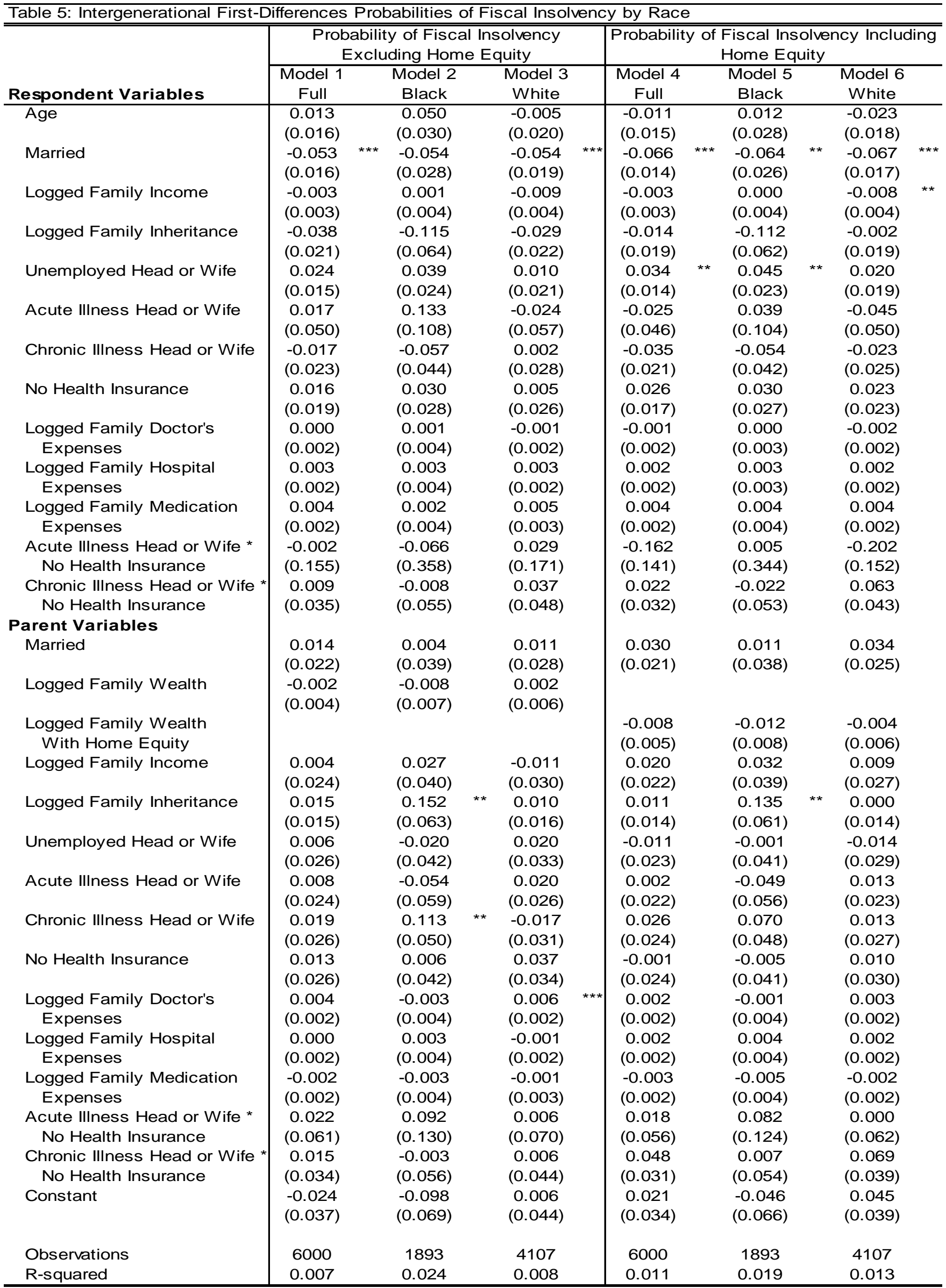

Standard errors in parentheses

$\star \star \star * ~ p<0.01, * \star p<0.05$ 